\title{
Clinical and epidemiological characteristics of patients with uveitis in an emergency eye care center in Brazil
}

\author{
Características clínicas e epidemiológicas das uveítes em um serviço de urgência oftalmológica no Brasil
}

Eduardo Nery Rossi Camilo ${ }^{1}$, Guilherme Lucena Moura ${ }^{1}$, Tiago Eugênio Faria e Arantes ${ }^{1,2}$

\begin{abstract}
Purpose: To analyze the clinical and epidemiological characteristics of patients with uveitis in an emergency eye care center.

Methods: We conducted a prospective, observational study of patients with active uveitis admitted between May 2012 and July 2012 to an emergency eye care center. Results: The majority of patients were male (63.2\%), with a mean age of 43.2 years; $66.2 \%$ patients were of mixed ethnicity, $22.5 \%$ were Caucasian, and $11.3 \%$ were black. Anterior uveitis was observed in $70.1 \%$ patients, posterior uveitis in $26.5 \%$, and panuveitis in 3.4\%; no patient was diagnosed with intermediate uveitis. All patients had a sudden and acute presentation. The most frequent symptoms were ocular pain (76.9\%), redness (59.8\%), and visual blurring (46.2\%). The majority of patients had unilateral disease (94.9\%) with a mean symptom duration of 6.2 days. Diffuse and anterior uveitis were associated with ocular pain $(p<0.001)$. Scotomata and floaters were more frequent in patients with posterior uveitis $(p=0.003$ and $p=0.016$, respectively). Patients with anterior uveitis presented with better visual acuity $(p=0.025)$. Granulomatous keratotic precipitates were more frequent in patients with posterior uveitis $(p=0.038)$. An etiological diagnosis based on the evaluation at the emergency center was made in 45 patients (38.5\%).

Conclusions: Acute anterior uveitis was the most frequent form of uveitis. Initial patient evaluation provided sufficient information for deciding primary therapy and aided in arriving at an etiological diagnosis in a considerable number of patients.
\end{abstract}

Keywords: Uveitis/etiology; Uveitis/epidemiology; Uveitis/diagnosis; Uveitis/classification; Emergencies

\section{RESUMO}

Objetivo: Analisar as características clínicas e epidemiológicas das uveítes em um serviço de atendimento oftalmológico de urgência.

Métodos: Estudo prospectivo, observacional de pacientes com uveíte ativa admitido entre maio ejulho de 2012, em um serviço de atendimento oftalmológico de emergência.

Resultados: A maioria dos pacientes eram do sexo masculino (63,2\%) e a média de idade foi de 43,2 anos; $66,2 \%$ dos pacientes tinham etnia mista, $22,5 \%$ eram brancos e $11,3 \%$ negros. Uveíte anterior foi observada em $70,1 \%$ dos pacientes, uveite posterior em $26,5 \%$, e panuveíte em 3,4\%, nenhum foi diagnosticado com uveíte intermediária. Todos os pacientes tiveram apresentação súbita e aquda. Os sintomas mais frequentes foram: dorocular (76,9\%), hiperemia conjuntival (59,8\%) ebaixavisual (46,2\%). A maioria dos pacientes tinha doença unilateral (94,9\%), com duração média dos sintomas de 6,2 dias. Uveites anteriores e difusas foram associadas com dor ocular $(p<0,001)$. Escotomas e a floaters" foram mais frequentes na uveíte posterior ( $p=0,003$ e $p=0,016$, respectivamente). Pacientes com uveite anterior apresentaram melhor acuidade visual $(p=0,025)$. Precipitados ceráticos granulomatosos foram mais frequentes em pacientes com uveíte posterior $(p=0,038)$. Um diagnóstico etiológico com base na avaliação inicial no serviço de emergência foi possível em 45 pacientes (38,5\%).

Conclusão: $A$ uveíte anterior aguda foi a uveíte mais frequentemente encontrada no serviço de urgência oftalmológica. A avaliação inicial do pacienteforneceu informações suficientes para a conduta terapêutica primária, e possibilitou diagnóstico etiológico em um número considerável de pacientes.

Descritores: Uveíteletiologia; Uveítelepidemiologia; Uveíte/diagnóstico; Uveíte/ classificação; Emergência

\section{INTRODUCTION}

Potential sight-threatening complications may occur if ocular inflammation is not diagnosed and treated early in the course of disea$\mathrm{se}^{(1-5)}$. However, initial evaluation of patients with uveitis is frequently conducted in nonspecialized centers because intraocular inflammation usually produces nonspecific symptoms such as pain, photophobia, redness, blurred vision, and floaters, which may easily be confused with other disorders ${ }^{(2,6)}$. In Brazil, uveitis is one of the main diagnoses in patients who attend institutions for visual rehabilitation ${ }^{(7)}$ and accounts for up to $7.4 \%$ visits to emergency eye care units. ${ }^{(8-11)}$.

The etiology of uveitis can be broadly categorized into infectious and noninfectious, and it is frequently associated with systemic disea$\mathrm{se}^{(12)}$. Several studies have investigated the epidemiology of uveitis, showing variations in etiology according to geographical region, gender, ethnicity, age, social aspects, and immunological factors. However, most of these studies have included patients from tertiary uveitis centers and may have been influenced by selection bias (1,, $13-18)^{(18}$. Globally, anterior uveitis accounts for the majority of cases ${ }^{(1,4,17,18)}$. However, posterior uveitis is the most common presentation in Brazilian patients, with toxoplasmic retinochoroiditis being the most frequent identifiable cause $\mathrm{e}^{(14-16)}$.

Identification of clinical and epidemiological patterns of uveitis is crucial to devise strategies for preventing late diagnosis and facilitating prompt treatment. Therefore, this study aimed to analyze the clinical and epidemiological characteristics of patients with uveitis who visited an emergency eye care center.

\section{METHODS}

This prospective study included patients with a clinical diagnosis of active uveitis who were treated between May 2012 and July 2012 in the emergency eye care center of Fundação Altino Ventura, a reference eye hospital for patients from the public health system of 
the state of Pernambuco, Brazil, which admits self-referred and professionally referred patients in all levels of care. Disease activity was defined by the presence of anterior chamber reaction, retinal or choroidal inflammation, and/or vitreous inflammation (if associated with macular edema or vasculitis). Patients with no signs of inflammatory activity of uveitis, those who had visited an outpatient uveitis clinic in the 3 months prior to consultation in the emergency department, those with a history of ocular trauma, and those with an uncertain diagnosis of uveitis were excluded.

The demographic and ophthalmological variables evaluated included age, gender, race, residence, symptoms, duration of symptoms, number of previous episodes, and clinical data from the ocular examination. Physical examination included presenting visual acuity (VA) measurement, external eye examination, slit-lamp biomicroscopy, indirect ophthalmoscopy, and applanation tonometry. Ancillary investigations were requested at the discretion of the examiners. Specific etiological diagnoses, when available, were based on the clinical data collected and tests requested at the initial consultation.

Anatomical and clinical classifications were determined according to established standard classification systems ${ }^{(12,19)}$. Only one eye of each patient was included in the analysis; in cases of bilateral involvement, the eye with more severe disease (higher grade of anterior chamber reaction or worse $V A$ if the inflammation was symmetrical) was analyzed.

Statistical analysis was performed using SPSS 16.0 for Windows (SPSS Inc, Chicago, Illinois, USA). Continuous variables are expressed as means \pm standard deviations, while categorical data are presented as frequencies. Relationships between categorical variables were assessed using Fisher's exact test. Analysis of variance (ANOVA) and Student's t test were used for the analysis of continuous variables. A $P$-value of $<0.05$ was considered statistically significant. The study was approved by the Institutional Review Board of Fundação Altino Ventura (\#053/2011). All patients signed a written informed consent form for this research.

\section{RESULTS}

During the period from May 2012 to July 2012, 480 patients with uveitis were examined in the emergency eye care center of Fundação Altino Ventura. Among these, 117 who had active uveitis and fulfilled the study requirements were included in the analysis. The mean age of the evaluated patients was $43.2 \pm 18.3$ years, and 74 (63.2\%) were male. Demographic data are shown in Table 1. There were no differences in the distribution of gender, race, and residence in relation to the anatomical classification of uveitis ( $p>0.05)$.

Anterior uveitis was observed in 82 patients (70.1\%), posterior uveitis in 31 (26.5\%), and diffuse uveitis in 4 (3.4\%); none of the patients were diagnosed with intermediate uveitis (Table 2). All patients presented with sudden and acute symptoms (less than 3 months duration). Patients with posterior uveitis were younger than those with either anterior uveitis or diffuse uveitis $(47.6 \pm 17.0$ years, $31.3 \pm 16.1$ years, and $46.0 \pm 24.2$ years, respectively, for anterior uveitis, posterior uveitis, and diffuse uveitis; $p<0.001)$.

The most common symptoms observed were eye pain $(n=90$, $76.9 \%)$, redness $(n=70,59.8 \%)$, and visual blurring $(n=54,46.2 \%)$. The majority of patients had unilateral disease $(n=111,94.9 \%)$, with a mean symptom duration of $6.2 \pm 6.3$ days. Eleven patients $(9.4 \%)$ had a previous diagnosis of uveitis and reported 1 to 5 previous episodes. None of the patients was being treated for uveitis at the time of evaluation; however, one patient was being treated for iatrogenic conjunctivitis.

The clinical characteristics of the patients and the physical examination findings are presented in Tables 3 and 4, respectively. Anterior and diffuse uveitis were associated with complaints of eye pain $(86.6 \%, 48.4 \%$, and $100.0 \%$, respectively, for anterior uveitis, posterior uveitis, and diffuse uveitis; $p<0.001)$. Scotomata were more frequent in patients with posterior uveitis $(1.2 \%, 19.4 \%$, and $0.0 \%$, respectively, for anterior uveitis, posterior uveitis, and diffuse uveitis; $p=0.003)$. Complaints about floaters were associated with posterior uveitis $(1.2 \%, 16.1 \%$, and $0.0 \%$, respectively, for anterior uveitis, posterior uveitis, and diffuse uveitis; $p=0.016$ ). Blurred vision was uncommon in patients with anterior uveitis when compared with inflammation at other sites (30.5\%, 80.6\%, 100.0\%, respectively, for anterior uveitis, posterior uveitis, and diffuse uveitis; $p<0.001)$. There was no significant association between the frequency of redness, photophobia, and photopsia with the anatomical classification of uveitis ( $p>0.05)$.

Patients with anterior uveitis showed better presenting VA (VA $>20 / 63$ in 57.0\%, 38.7\%, and $0.0 \%$, respectively, for anterior uveitis, posterior uveitis, and diffuse uveitis; $p=0.025)$. Conjunctival hyperemia was more common in patients with anterior uveitis $(91.5 \%$, $64.5 \%$, and $75.0 \%$, respectively, for anterior uveitis, posterior uveitis, and diffuse uveitis; $p=0.003$ ). Patients with granulomatous keratotic precipitates were most often diagnosed with posterior uveitis $(3.7 \%$, $19.4 \%$, and $0.0 \%$, respectively, for anterior uveitis, posterior uveitis, and diffuse uveitis; $p=0.038$ ). There was no association of the frequency of posterior synechiae, fine keratotic precipitates, iris nodules, and anterior chamber cells grade with the anatomical classification of uveitis ( $p>0.05)$. The mean intraocular pressure at presentation was $13.9 \pm 7.2 \mathrm{mmHg}$ (range, 2.0 to $40.0 \mathrm{mmHg}$ ), and there was no statistical association between intraocular pressure and the anatomical classification of uveitis $(p=0.598)$.

Table 1. Demographic characteristics of patients with active uveitis treated at the emergency eye care center of Fundação Altino Ventura, Recife, Brazil, between March and July 2012 ( $n=117$ )

\begin{tabular}{|c|c|c|}
\hline \multicolumn{3}{|l|}{ Age (years) } \\
\hline \multicolumn{2}{|c|}{ Mean \pm standard deviation, (range) } & $43.2 \pm 18.3(8-89)$ \\
\hline \multicolumn{3}{|l|}{ Gender [n (\%)] } \\
\hline \multicolumn{2}{|l|}{ Female } & $43(36.8)$ \\
\hline \multicolumn{2}{|l|}{ Male } & $74(63.2)$ \\
\hline \multicolumn{3}{|l|}{ Ethnicity $[n(\%)]^{+}$} \\
\hline \multicolumn{2}{|l|}{ Caucasian } & $16(22.5)$ \\
\hline \multicolumn{2}{|l|}{ Black } & $8(11.3)$ \\
\hline \multicolumn{2}{|l|}{ Mixed race } & $47(66.2)$ \\
\hline \multicolumn{3}{|l|}{ Place of residence $[n(\%)]^{+}$} \\
\hline \multicolumn{2}{|l|}{ Recife } & $24(33.8)$ \\
\hline \multicolumn{2}{|c|}{ Other cities in the metropolitan region } & $27(38.0)$ \\
\hline \multicolumn{2}{|l|}{ Other cities in states } & $19(26.8)$ \\
\hline \multicolumn{2}{|l|}{ Other states } & $1(1.4)$ \\
\hline \multicolumn{3}{|c|}{${ }^{+}=$data on ethnicity and residence were not collected for 46 patients $(n=71)$. } \\
\hline \multicolumn{3}{|c|}{$\begin{array}{l}\text { Table 2. Anatomical classification and frequency of determination o } \\
\text { a cause or clinical syndrome on the basis of initial evaluation of } 117 \\
\text { patients with active uveitis treated at the emergency eye care cente } \\
\text { of Fundação Altino Ventura, Recife, Brazil between March and July } \\
2012 \text { [n (\%)] }\end{array}$} \\
\hline Anatomical classification & $\begin{array}{c}\text { Total patients } \\
\text { n (\%) }\end{array}$ & $\begin{array}{l}\text { Patients with specific diagnoses } \\
\text { n (\%) }\end{array}$ \\
\hline Anterior uveitis & $82(70.1)$ & $14(17.1)$ \\
\hline Intermediate uveitis & $0(0.0)$ & $0(0.0)$ \\
\hline Posterior uveitis & $31(26.5)$ & $27(87.1)$ \\
\hline Panuveitis & $4(\quad 3.4)$ & $4(100.0)$ \\
\hline Total & $117(100.0)$ & $45(38.5)$ \\
\hline
\end{tabular}


Table 3. Clinical characteristics of patients with active uveitis treated at the emergency eye care center of Fundação Altino Ventura, Recife, Brazil between March and July $2012(n=117)$

\begin{tabular}{lr}
\hline Laterality [n(\%)] & $111(94.9)$ \\
Unilateral & $6(5.1)$ \\
Bilateral & \\
Duration of symptoms (days) & $6.2 \pm 6.3(1-30)$ \\
Mean \pm standard deviation, (range) & \\
Symptoms [n (\%)] & $54(46.2)$ \\
Blurred vision & $70(59.8)$ \\
Redness & $90(76.9)$ \\
Pain & $31(26.5)$ \\
Photophobia & $7(6.0)$ \\
Scotomas & $6(5.1)$ \\
Floaters & $2(1.7)$ \\
Fotopsias & $11(9.4)$ \\
Previous diagnosis of uveitis [n (\%)] & \\
\hline
\end{tabular}

Table 4. Ocular examination findings of the patients with active uveitis treated at the emergency eye care center of Fundação Altino Ventura, Recife, Brazil between March and July 2012 ( $n=117)$

\begin{tabular}{|c|c|}
\hline \multicolumn{2}{|l|}{ Visual acuity $[\mathrm{n}(\%)]^{\dagger}$} \\
\hline$>20 / 63$ & $57(50.0)$ \\
\hline $20 / 63$ to $20 / 200$ & $29(25.4)$ \\
\hline$<20 / 200$ & $28(24.6)$ \\
\hline \multicolumn{2}{|l|}{ Anterior segment [n (\%)] } \\
\hline Conjunctival hyperemia & $98(83.8)$ \\
\hline Fine keratic precipitates & $48(41.0)$ \\
\hline Granulomatous keratic precipitates & $9(7.7)$ \\
\hline Corneal edema & $19(16.2)$ \\
\hline Keratitis & $10(8.5)$ \\
\hline Posterior synechiae & $24(20.5)$ \\
\hline$<180^{\circ}$ & $15(12.8)$ \\
\hline$>180^{\circ}$ & $9(7.7)$ \\
\hline Iris nodules & $1(0.9)$ \\
\hline \multicolumn{2}{|l|}{ Anterior chamber cell reaction ${ }^{\ddagger}$} \\
\hline $0+$ cells & $10(8.8)$ \\
\hline 0.5 to $2+$ cells & $63(55.3)$ \\
\hline$>2+$ cells & $41(36.0)$ \\
\hline Hypopyon & $3(2.6)$ \\
\hline \multicolumn{2}{|l|}{ Posterior segment $[n(\%)]^{\S}$} \\
\hline Vitreous opacity & $24(21.6)$ \\
\hline Retinochoroiditis & $24(21.6)$ \\
\hline Retinitis & $1(0.9)$ \\
\hline Exudative retinal detachment & $2(1.8)$ \\
\hline
\end{tabular}

Intraocular pressure $(\mathrm{mmHg})^{9}$

Mean \pm standard deviation, (range)

$=$ visual acuity measurement was not possible in 3 patients $(n=114):{ }^{\neq}=$evaluation of anterior chamber reactions was not possible in 3 patients $(n=114) ;=$ evaluation of posterior segment was not possible in 6 patients $(n=111) ;=$ applanation tonometry was not possible in 18 patients $(n=99)$.
Etiological diagnosis was established in 45 patients (38.5\%) on the basis of the clinical evaluation and ancillary laboratory tests requested at the initial visit. Among the 82 patients with anterior uveitis, 68 (82.9\%) had an unknown etiology (of these, 63 had their first episode of anterior uveitis and were not investigated), 8 (9.8\%) had uveitis associated with rheumatological disease, and 6 (7.3\%) had a herpetic etiology. Among the 31 patients with posterior uveitis, 26 $(87.1 \%)$ had an etiological diagnosis established during the initial visit, 25 (83.9\% of posterior uveitis) had toxoplasmic retinochoroidits, and 1 (3.2\%) patient had herpetic retinitis (acute retinal necrosis). Among the 4 patients with diffuse uveitis, 2 (50\%) were diagnosed with Vogt-Koyanagi-Harada disease, 1 (25\%) with fungal endophthalmitis, and $1(25 \%)$ with hypersensitivity uveitis caused by a corneal bee sting (Table 2).

\section{DISCUSSION}

This study prospectively evaluated patients from an emergency eye care center, in contrast to most uveitis epidemiological studies that have been conducted retrospectively in tertiary specialized centers ${ }^{(1,4)}$. In previous studies from referring uveitis centers in Brazil, including our institution, posterior uveitis accounted for the majority of cases, particularly toxoplasmosis ${ }^{(14-16)}$. In contrast, anterior uveitis was responsible for $70.1 \%$ patients in our study. This can be explained by the fact that our sample mostly included individuals with firstepisode anterior uveitis; these patients are typically not referred to specialized centers for investigation. The high frequency of anterior uveitis was in accordance with that reported in studies conducted in specialized uveitis centers in other countries $s^{(1,4,17)}$ and studies conducted in community-based eye care centers ${ }^{(18)}$.

The mean age of patients in this study ( 42.6 years) was higher than that reported in a previous study conducted at our institution between 1998 and 1999 (32.1 years) ${ }^{(14)}$ and in studies conducted in referring centers in Colombia and Tunisia (31.7 and 34.0 years, respectively) ${ }^{(13,17)}$. Nevertheless, the mean age of patients in the present study was similar to that in studies from North America (45 years) ${ }^{(18)}$ and Southeastern Brazil (41 years) ${ }^{(16)}$. Most patients in our study were working adults, similar to the patients in the previous studies. The incidence of uveitic entities has been associated with ethnicity ${ }^{(1,4)}$; however, we could not find such an association, possibly because of the mixed race background of the Brazilian population.

The most frequently reported symptoms were pain, redness, blurred vision, and photophobia. Such symptoms are nonspecific and can be easily misdiagnosed as other conditions, including conjunctivitis and keratitis ${ }^{(6)}$. Anterior uveitis was associated with a higher frequency of redness and pain, while posterior uveitis was greatly associated with blurred vision and scotomata. Granulomatous keratotic precipitates were most common in patients with the primary site of inflammation in the posterior segment. Therefore, an accurate medical history and physical examination are imperative for establishing a diagnosis in patients with uveitis.

Determination of a cause or clinical syndrome on the basis of clinical presentation and ancillary examination requested at the initial visit was possible in $38.5 \%$ patients, a diagnostic rate lower than that observed in community-based, comprehensive ophthalmological units and uveitis referral centers (46\% to $79.4 \%)^{(1,4,13,17,18)}$. In this study, first-episode acute anterior uveitis accounted for the majority of cases. It should be noted that further investigations are usually not performed in patients presenting with the first episode of uncomplicated anterior uveitis ${ }^{(20)}$, which explains the high frequency of uveitis of unknown etiology.

This research mostly included patients who were visiting the hospital for the first time, and the onset and course of disease were based on symptomatology, which can lead to misclassification. For example, a patient with an exacerbation of undiagnosed chronic uveitis could have been incorrectly diagnosed with sudden-onset acute uveitis ${ }^{(18)}$. Another limitation of this study was the small sample size, which may have restricted the inclusion of less common uveitic entities. 
In conclusion, this study shows that anterior uveitis is observed more frequently in primary health care centers than in tertiary referral centers. Initial evaluation of the patient in the emergency room provided sufficient information for deciding primary therapy and aided in arriving at an etiological diagnosis in a considerable number of patients. These findings are important for prioritization of education and training for general ophthalmologists.

\section{REFERENCES}

1. Chang JH, Wakefield D. Uveitis: a global perspective. Ocul Immunol Inflamm. 2002 10(4):263-79. Review.

2. Gutteridge IF, Hall AJ. Acute anterior uveitis in primary care. Clin Exp Optom. 2007; 90(5):390; author reply 390

3. Prieto-del-Cura M, González-Guijarro J. [Complications of uveitis: prevalence and risk factors in a series of 398 cases]. Arch Soc Esp Oftalmol. 2009;84(10):523-8. Spanish.

4. Rathinam SR, Namperumalsamy P. Global variation and pattern changes in epidemiology of uveitis. Indian J Ophthalmol. 2007;55(3):173-83. Review.

5. Durrani OM, Meads CA, Murray PI. Uveitis: a potentially blinding disease. Ophthalmologica. 2004:218(4):223-36. Review.

6. Mahmood AR, Narang AT. Diagnosis and management of the acute red eye. Emerg Med Clin North Am. 2008;26(1):35-55, vi. Review.

7. Kara-José N, Carvalho KM, Pereira VL, Venturini NH, Gasparetto ME, Gushiken MT. [Retrospective study of first 140 cases attended the Clinica de Visäo Sub-Normal of the Hospital de Clínicas da Unicamp]. Arq Bras Oftalmol. 1988:51(2):65-9. Portuguese

8. Carvalho Rde S, José NK. Ophthalmology emergency room at the University of São Paulo General Hospital: a tertiary hospital providing primary and secondary level care. Clinics (Sao Paulo). 2007;62(3):301-8.
9. Campos Júnior JC. [Profile of ophthamological attendance of emergency]. Rev Bras Oftalmol. 2004;63(2):89-91. Portuguese.

10. Kumar NL, Black D, McClellan K. Daytime presentations to a metropolitan ophthalmic emergency department. Clin Experiment Ophthalmol. 2005;33(6):586-92.

11. Pierre Filho PT, Gomes PR, Pierre ET, Pinheiro Neto FB. [Profile of ocular emergencies in a tertiary hospital from Northeast of Brazil]. Rev Bras Oftalmol. 2010;69(1):12-7. Portuguese.

12. Deschenes J, Murray PI, Rao NA, Nussenblatt RB; International Uveitis Study Group. International Uveitis Study Group (IUSG): clinical classification of uveitis. Ocul Immunol Inflamm. 2008;16(1):1-2.

13. de-la-Torre A, López-Castillo CA, Rueda JC, Mantilla RD, Gómez-Marín JE, Anaya JM. Clinical patterns of uveitis in two ophthalmology centres in Bogota, Colombia. Clin Experiment Ophthalmol. 2009;37(5):458-66.

14. Diniz JR, Toscano JL, Campelo DE, Delgado AC, Leal SD. [Occurency of uveitis in Pernambuco state, Brazil]. Rev Bras Ciênc Saúde. 2001;5(1):59-64. Portuguese.

15. Gehlen ML, Dabul VM, Obara SS, Grebos SP, Moreira CA. [Incidence and etiology of uveitis in Curitiba]. Arq Bras Oftalmol. 1999;62(5):622-6. Portuguese.

16. Gouveia EB, Yamamoto JH, Abdalla M, Hirata CE, Kubo P, Olivalves E. [Causes of uveitis in a tertiary center in São Paulo city, Brazil]. Arq Bras Oftalmol. 2004;67(1):139-45. Portuquese.

17. Khairallah M, Yahia SB, Ladjimi A, Messaoud R, Zaouali S, Attia S, et al. Pattern of uveitis in a referral centre in Tunisia, North Africa. Eye (Lond). 2007;21(1):33-9.

18. McCannel CA, Holland GN, Helm CJ, Cornell PJ, Winston JV, Rimmer TG. Causes of uveitis in the general practice of ophthalmology. UCLA Community-Based Uveitis Study Group. Am J Ophthalmol. 1996;121(1):35-46.

19. Jabs DA, Nussenblatt RB, Rosenbaum JT; Standardization of Uveitis Nomenclature (SUN) Working Group. Standardization of uveitis nomenclature for reporting clinical data. Results of the First International Workshop. Am J Ophthalmol. 2005;140(3):509-16. Review.

20. Forooghian F, Gupta R, Wong DT, Derzko-Dzulynsky L. Anterior uveitis investigation by Canadian ophthalmologists: insights from the Canadian National Uveitis Survey. Can J Ophthalmol. 2006:41(5):576-83.

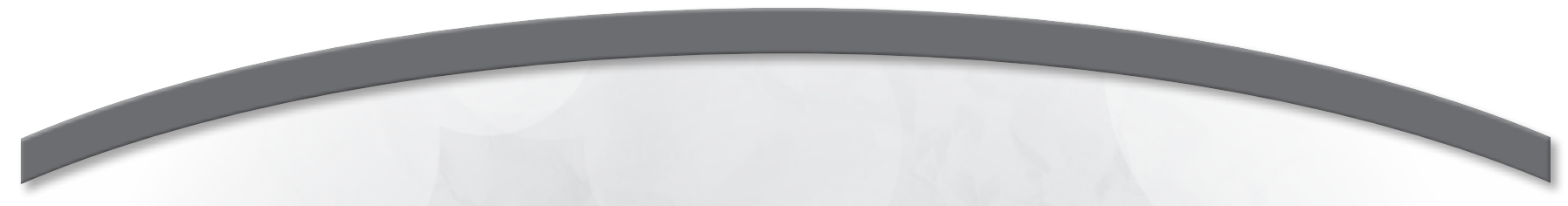

\title{
XXI Simpósio Internacional de Atualização em Oftalmologia da Santa Casa de São Paulo
}

\author{
28 a 31 de maio de 2014 \\ Centro de Convenções do Clube A Hebraica \\ São Paulo - SP \\ Informações: \\ E-mail: secret.diroftalmo@santacasasp.org.br \\ JDE Eventos - Tels.: (11) 5084-5284 / 508 4-9174 \\ Site: http://www.oftalmosantacasa.com.br
}

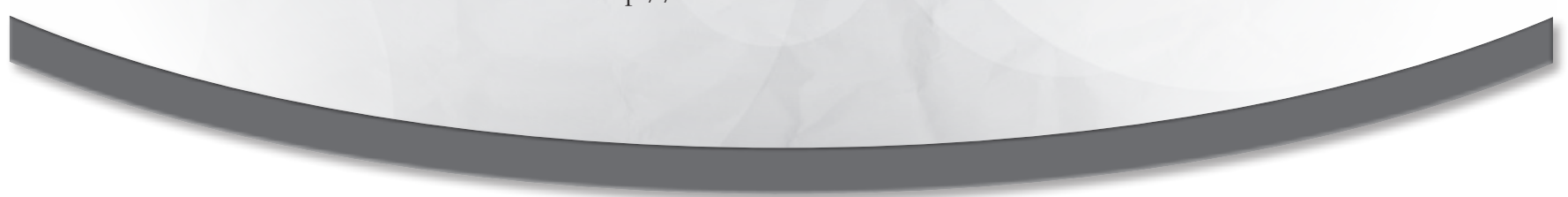

